\title{
The Academicians on Quarantine: Reflexivity and Fragility of the Privileged Group at the Start of Pandemic*
}

\author{
Daria Litvina \\ Research Fellow, Faculty of Sociology, Institute for Interdisciplinary Health Research; \\ Senior Lecturer, Master's Program "Social Studies of Health and Medicine", \\ European University at Saint Petersburg \\ Address: Gagarinskaya str., 6/1A, St. Petersburg, Russia 191187 \\ E-mail: dlitvina@eu.spb.ru \\ Anna Temkina \\ Professor, Chair in Public Health and Gender, co-director of the Gender Studies Programme, \\ European University at St. Petersburg \\ Address: Gagarinskaya str., 6/1A, St. Petersburg, Russia 191187 \\ E-mail: temkina@eu.spb.ru
}

\begin{abstract}
The goal of this article is to analyze the challenges faced by social researchers during the first months of the pandemic of 2020 when work-life issues were problematized and academic routine changed. The article is based on a dataset of diaries in which researchers with an academic background in social sciences and humanities were fixing their everyday life and reflecting on its changes. We explore why academicians, a relatively privileged group due to their possibilities of safe remote-working and maintaining professional obligations during the period of lockdown, experienced strong moral emotions related to work. We argue that basic references of space and time lost their routine structure, hindered work productivity, and threatened the "proper", disciplined, and productive academic self. In their written narratives, participants of the project describe different emotional responses to this situation, with a focus on negative feelings including anxiety and guilt. The new reality was characterized by the layering of previously separated tasks at the same time and space boundaries, and therefore, in overload. At the same time, academicians were deprived of routine forms of faceto-face professional communications and networking. Academicians are oriented towards self-discipline and productivity, and self is produced via normative (self) evaluation and the juxtaposition with reference group(s). When the rules are changed, unstable, or constantly violated, it threatens the self. Moral emotions indicate this process until the new social order becomes inhabited and routinized.
\end{abstract}

Keywords: COVID-19, pandemic, emotions, academia, self, diaries, scholars

\section{Introduction}

At the end of 2019 and the beginning of 2020, the world faced an unprecedented global challenge of the pandemic caused by the SARS-CoV-2 virus. At that time, different pre-

${ }^{*}$ We are very thankful to Marina Hakkarainen, Elena Zdravomyslova, and Mikhail Sokolov for their valuable comments to this article. We also express our gratitude to Irina Tartakovskaya and Anastasia Novkunskaya for their consultations and comments during the project. Finally, we want to thank all of the participants of our project for sharing their experiences, evaluations, and emotions in these turbulent times.

The research was supported by European University at Saint Petersburg. 
ventive measures such as lockdowns and restrictions were introduced around the world. The pandemic has led to various social consequences, and has provoked many challenges for different countries, institutions, social and professional groups, and individuals. The COVID-driven economic and vital risks, although having increased everywhere, have been unevenly distributed between and within societies. While some professional groups appeared to be at the frontlines working at indispensable positions in the medical, service, industrial and transport sectors, many others found themselves in new, precarious positions (e.g., remaining unemployed), while a few found themselves in relatively safe spaces with newly opened opportunities for business (for example, Risi et al., 2020; Baltic Rim Economies. 2021. № 3: A special issue on COVID-19 ${ }^{1}$ ).

Extensive research has already been done focusing on the groups that are associated with the most apparent forms of vulnerabilities during the pandemic; especially physical (the ones unable to stay in safe conditions or from groups at risk) and financial (the ones who lost their sources of income). These are medical providers, women (e.g., the ones experiencing domestic violence or working mothers whose care duties incrementally increased), self-employed people, the elderly, etc. (see Crook, 2020; Minello et al., 2021; Kınıkoğlu, Can, 2021). The roles of class, age, and gender in the ways people were experiencing them during the times of isolation became vivid in many aspects.

Here, we are interested in a group of Russian-speaking academicians, and would like to explain how and why this privileged group that could stay in safe spaces at home and maintain their professional obligations during the COVID-19 outbreak experienced strong moral emotions related to their profession and felt vulnerable during the first months of the pandemic year 2020.

In Russia, the massive discourse about the local manifestations of COVID-19 started in early March, 2020, soon after centralized measures of regulation were introduced. Vladimir Putin's presidential appeal to the citizens of Russia on the 25th of March, 2020, (President of Russia, 2020) became the official start of the self-isolation regime, which was unofficially called and appreciated by the citizens as "long holidays" (28 March -5 April). It presupposed that many institutions had to provide paid days off for their workers. The universities, kindergartens and schools, many shops, and cultural and entertainment institutions were closed or (if possible) had to switch to an online format. After that, the non-working days were prolonged to 30 April. The first month of the pandemic was characterized by disappointment, that is, the quick release from the coronavirus appeared to be indistinguishable (Oslon, 2021: 67). Since then, the measures and rules of protection and prophylactics have been constantly changing by becoming stricter or looser, which made them look inconsistent and controversial.

In this article, we are interested in what happened to academic workers (professors, teachers, researchers, and $\mathrm{PhD}$ students): what was their subjective experiences of worklife balance and academic routine under COVID-19? We considered academic social science and humanities as a variation of creative, mobile, relatively autonomous professions

1. https://sites.utu.fi/bre/baltic-rim-economies-3-2021/ 
with relatively high prestige, with a flexible organization of space and time, and with some certain criteria of activities and results (publications, teaching, research, conferences' participation, and media activities). When their work was brought online, academicians faced various challenges, including the ones many other middle class remote workers also faced.

Studies of remote work during the pandemic show strongly-negative emotional responses to isolation, to the challenges related to a work-life balance, to the increase in domestic violence, to a work overload or, the opposite, to a lack of work, numerous technical challenges, and negative effects on mental and physical health (review of research in Tahir, 2021). Distance-workers lost the ability to maintain their professional sociability on a daily basis in face-to-face interactions (the summary can be found in Reuschke, 2021). However, the process is ambivalent. Distance work also produce benefits such as the possibilities for obtaining new skills, a flexibility in work, an increase in using technology, saving time, and better control (Tahir, 2021). According to research of distant work in the UK in 2020 when the number of remote workers increased radically, especially among the youngest and more educated professionals, "many workers have got used to and may even have experienced the benefits of working at home. In addition, productivity has not been adversely affected by the shift towards homeworking" (Reuschke, 2021).

However, each professional group of remote workers has its own peculiarities. In particular, the positioning of academic workers during the pandemic is confusing since they could (and managed to) work remotely, fulfilling their professional obligations along with keeping (to more or less extent) their income, but, according to our data, they (we) ${ }^{2}$ felt predominantly insecure, vulnerable, and frustrated. The same results are shown by other studies: in the USA, the faculty expresses feelings of being "overwhelmed", "frustrated" and "stressed" while taking responsibility for on-line classes (Bidwell et al, 2021: 39-40). According to a Russian survey, $61 \%$ of all remote workers (19\% of which are the ones working in education) disliked this format, $47 \%$ claimed that the content and organization of their work changed, $37 \%$ noted that their work had worsened, and $22 \%$ reported working more than 9 hours per day (i.e., overworking) (Oslon, 2021: 104-105).

In order to explain this, we will demonstrate how a "proper" academic life-work balance and a "proper" academic professional are framed by routine spatial, temporal, and communicative referents which were challenged during the corona crisis. We will not go deeper into discussion on the precarization of researchers under the neo-liberalization of academia as our focus is on the special context of the COVID-19 lockdown and distance work.

For our explanation, the following categories are important: "reflexive self" (which we use interrelatedly with the terms "self", "subjectivity", or "subjective experiences"), "narrativization", and "emotions". We use the category "self" while exploring how the "academic self" was challenged by rapid social changes and required to be reevaluated in interactions (Goffman, 1990). We argue that self is reflexive, intersubjective, and dynami-

2. As we were among the authors of diaries, we intentionally use both "they" and "we" when we speak about participants of the project in this text. 
cally shaped by social, economic, and political processes (see more on reflexive self at Adams, 2003). COVID-19 appears to be the exterior factor that launches the process of re-considering the self of social scholars. This becomes evident through the process of the narrativization of self-reflections and concurrent emotions of social scholars during the first wave of coronavirus in Russia. In this article, we do not discuss the long-term consequences of the coronavirus pandemic for the self of social scholars (which is a subject for further investigation), but rather argue that the professional self is a matter of ongoing reflections which can be triggered by changing patterns of everyday life (time and space in particular). As Anthony Giddens puts it,

The reflexivity of modern social life consists in the fact that social practices are constantly examined and reformed in the light of incoming information about those very practices, thus constitutively altering their character. We should be clear about the nature of this phenomenon. All forms of social life are partly constituted by actors' knowledge of them. Knowing "how to go on" in Wittgenstein's sense is intrinsic to the conventions which are drawn upon and reproduced by human activity. (1990: 38)

Difficulties with routine practices, as we will show further, provoke the narrativization of self (Giddens, 1991) of some scholars. The rupture of human narratives during the coronavirus pandemic led to the losing of grace, appeal, and interest (Fernandez, 2021). Metaphorically speaking, narratives in first months of corona times are, to some extent, similar to the production of "therapeutic" narratives by chronically ill persons who try to get back one's subjectivity (Frank, 1995), or in terms of therapeutic culture (Illouz, 2007; Lerner, 2015); academic workers produce self, especially under the rupture of frame of references, through emotional language, even if it is supposed that the "ideal academic" is an "unembodied worker" (Utoft, 2020), that is, one without emotions.

In this article, our logic is as follows; we will describe the diary project and the collected data; after this, we will turn to the results of our empirical research and explore the temporal and spatial changes of basic social references of the everyday and the professional life of academic workers. We will show how and why strong moral emotions, such as anxiety, guilt, and shame, accompany this process. After this, we will turn to exploring the ongoing reflexive processes with our professional selves during this time, and related coping strategies.

\section{Data and Method: The Diaries of the Researchers}

This project "Virus Diaries: Chronicles of Everyday Life" (moderated by Anna Temkina and Daria Litvina) started in March, 2020, and continued up to June, 2020; an additional 5th wave was conducted in September, 2020, to get the update on the reflections and situations. Therefore, we gathered data in five "waves".

3. Start: (10) 25 March; the 1st wave - up to 5 April; the 2nd wave - up to 21 April; the 3 rd wave - up to 12 May; the 4 th wave - up to 10 June; and the 5 th wave - up to 30 September. 
There was a total of 34 scholars (the authors included) from ten countries who participated in the project. Most of the participants live in Russia (Saint-Petersburg or Moscow), others wrote from Australia, Azerbaijan, Armenia, Georgia, Germany, France, Finland, Sweden, and the USA. All participants are Russian-speaking (a few are bilingual) researchers from such academic fields as sociology (the majority), philosophy, philology, anthropology, political studies, history, and oriental studies. There are 8 men and 26 women of different age groups (aged 23-67) and professional statuses, from PhD students to professors. Most of the participants are living in nuclear families without children $(n=16)$, the rest live with children $(n=5)$, in extended families $(n=6)$, in individual households $(n=6)$, or with friends $(n=1)$. During the project, all of the participants were in self-isolation (to a different extent) and worked remotely from home. They tried to follow the safety rules as proposed by experts or designed by themselves, and rarely violated them.

Participants were recruited among those researchers whom the authors of this article know personally, and therefore belong to a networking academic community. We also refer to this community as middle-class remote workers; therefore, results of this study could be expanded to some extent and compared to other professional groups of such status.

Participants were suggested to write a diary in free form (which they did), although the following topics were recommended to cover: coping with risks and safety; behavior and interactions of people in a city/public places and institutions; the reorganization of professional and everyday lives; the transformations of personal/family/intimate relationships; communications with friends; emotions; and, finally, discourses and politics. The genre of the texts de facto represents both personal reflections and research observations.

This project resulted in a database of records on pandemic daily routines which was available for all of the participants who shared their diaries with the rest of the group. ${ }^{4}$ Participants were informed about the academic purposes of the project and the ethical rules of using the data (a written confirmation via e-mail was required). The data was available to all participants who intend to use it for academic purposes.

The idea of the project emerged in the early spring of 2020 when we noticed an increasing narrativization of current changes and subjective experiences. People around us (including ourselves) started to write diaries, make online publications, and created numerous chats in social media in order to fix the new social reality and, at the same time, to cope with its' instability and challenges. The quick overview and consultation with colleagues abroad showed that there was an international rise in number of projects related to pandemic experiences, such as oral history projects, various collections of diaries, and other narrated evidences.

Therefore, we decided to make a closed call and invite a circle of our trustworthy academic acquaintances to write diaries. Most of our colleagues enthusiastically agreed to participate in this project, as some of them had already been writing diaries or making

4. The project already has two publications: on (mis)trust (Tartakovskaya, 2021), and on social inaction (Holavin, 2020). 
notes, while some others told us that they were just about to write down their experiences. For many of them, writing diaries constitutes a kind of research and/or coping strategy. They evaluated our proposal positively and continued their writing with a purpose, as researchers:

[This diary] is "on the occasion", due to the circumstances. There is a virus, there is isolation, and being in isolation is very difficult. I began to write something down just to remember the days ... I am constantly reading and writing this diary as a researcher as well ... I am thinking about the things in my current life a researcher may be interested in ... This is an interesting reflective work. I am glad it happens.

(Svetlana ${ }^{5}$, April 2020)

This diary is very useful. I will continue to take notes. It is very disciplining, especially if the task is thematized.

(Nina, June 2020)

We realize that our project has potential biases that we need to list. First, we recruited those who belonged to a certain social circle (although not necessarily acquainted with each other), and therefore had a good chance of having similar "academic selves". Second, the process of writing diaries is a time-consuming practice that could be accomplished only by those who were reflexive and sensitive to the ongoing changes, to the extent that they were ready to share their experience with community members.

Despite the limitations mentioned, we fixed a social phenomenon that was evident worldwide, that is, a rise of narrativization of subjective experiences (the self) triggered by rapidly-changing everyday life patterns and accompanied by strong moral emotions. The process obviously touched a huge section of our professional community, though we have no instrument to count the numbers. Therefore, we seek to address the mechanics of the process rather than its prevalence.

\section{The Changing Temporal and Spatial Dimensions of Pandemic Work and Life}

For academic professionals (including those participants from countries with different principles and timing of lockdowns), the short and long-lasting effects of the pandemic were associated with remote teaching, restrictions of academic mobility (international conferences, fellowships, etc.), the unavailability of full-scale ethnographic work, the lack or absence of offline intellectual events (seminars, book presentations, debates, etc.), and changes in their daily relations with colleagues, students, and administration.

The majority of the participants narrated how difficult it was to start working or studying in new remote conditions; their productivity declined, causing emotional responses, feelings of anxiety, shame, and guilt. In rare cases, participants said that not much changed in their lives: they kept on working, reading, writing, teaching, and conducting research as before. Moreover, a few participants welcomed the new possibilities,

5. In this text names of all participants were changed into pseudonyms. 
e.g., the increase in online communication which allowed them to easily contact international colleagues, or saving time which they had to spend on going to meetings. One participant wrote that

For me, however, quarantine is a kind of relief: as least I do not feel guilt of not attending this or that exhibition, seminar, or party.

(Kristina, April 2020)

Nevertheless, even those who were fine with remote working reported physical and emotional discomfort related to the changing patterns of their everyday routine as predetermined by spatial and temporal coordinates; their routines had to be reconsidered. In this section, we will explore how temporal and spatial coordinates of everyday and professional life were presented in diaries. We will show how they lost their structural capacities, problematized academic practices and the "academic self", and caused intensive emotional response in many participants (which we address in more detail in the next section).

\section{Work-Life Balance Problematized}

Spatial and temporal references appear to be the carcass of everyday life. These referents routinely, invisibly, and non-reflexively organize our professional life and other activities. It is important that "a shared everyday life has to be synchronized by way of temporal orderings and choreographies, and by juggling competing activities throughout the day (e.g., work-life balance)" (Damsholt, 2020: 140).

During corona, crisis planning of time and the "synchronization" of time and space between actors became highly problematic. Competing activities emerged in the spheres in which they did not simultaneously exist previously. In the situation of multi-dimensionality, tasks (both working and caring) could be appointed to the same time, with no obvious priority of one over another. The working rhythm was intensified, but housework was intensified as well. Participants describe their struggle when the kindergartens and schools were closed, children and other family members remained home, online teaching combined with online meetings and ethnographies. Everything was happening in the same space and at the same time.

The volume of housework and care increased, and the delegation of these duties to outsourcing became unsafe and uneasy. Care is described by researchers as a problematic issue during the worldwide corona crisis (see, for example, Fodor et al., 2020; Hjálmsdóttir, Bjarnadóttir, 2020). Caring for children (including the organization of their teaching and entertaining), cooking, and cleaning constituted new competing activities for the participants in the assemblage of multiple concurrent tasks, both professional and caring. Special efforts were made to cope with them, but nevertheless, the process did not become more controlled. As one participant describes her attempt to rule her and her family's time: 
I made a schedule, taking into account all the things that were necessary and useful from my point of view: classes with [daughter] (20 minutes of reading in Russian and 15 minutes of reading in [another language], as the school orders), cooking, time for dressing the children and their management, walking, cleaning ... It turned out that there were literally 2 hours left for my own tasks, and then they were split into one-hour intervals. Immediately, everything did not go according to plan: the children do not want to do anything and do not listen to me.

(Inga, March 2020)

Suddenly, we were blocked in our homes and had to systematically re-negotiate with family members and colleagues about work-life issues, which led to the intensification of communications and competition not only between activities, but also between partners or family members for personal and working time and space.

Participants faced the problems of role-balancing and multitasking, and the diaries are full of descriptions of caring and working without any boundary or break between them. Everything became scheduled at the same time and the same place, all day, around the clock:

During the second half of the day I was sitting with a child. She really needs my attention. I feel that I help her little, can't entertain her, can't fully participate in her games. I keep on thinking how to snatch time for work.

(Marina, May 2020)

I sat on the ottoman (my back, shoulders and legs are already very tired) to write a couple of working letters to better plan the work for the week. Between work issues I manage to change diapers for my son.

(Valeria, September 2020)

Household work intensified in families with kids, as it became necessary to constantly cook for the whole family, clean, and coordinate activities: "It seems that work has intensified in the remote mode as well, because there is an illusion that it is always convenient for everyone to do any work" (Valeria, March 2020). Competing activities desynchronize the routine of previously structured time and space, and influence time perception and work productivity.

\section{Accelerated Time}

Researchers are supposed to have intensive but relatively flexible rhythms of professional life and reflexive independent selves and individual practices. The pandemic, paradoxically, sheds light on their dependence on the synchronization of time and space with other scholars. During lockdown, time doesn't follow a predefined schedule. We can observe a "temporalization of time" (Rosa, 2013), or "timeless time" (Castells, 1996). The time is subjectively experienced as a scarce resource which is difficult to control and allocate, and this was the main leitmotif of the diaries. The participants reported difficulties with 
short- and long-term time management, lack of temporal organizational structure, and a different "speed" of time. They (we) spoke about

Timelessness, time dilation ... Days merged into one big stream.

(Sofia, April 2020)

Time either erases or disappears, or there is just nothing to remember.

(Svetlana, May 2020)

I am catastrophically late with everything.

(Valeria, March 2020)

As a result, "extra time" that was "saved" on transportation to work and cancellations of offline events vanished along with optimistic plans on "long holidays":

At the beginning of the quarantine, it seemed that now I'll move mountains I'll finish my articles, I'll progress with the book — but everything is going much slower. Some days have gone to waste.

(Victor, May 2020)

If previously we could orient ourselves on planning and performing one task at a time (not only within life-work balance, but also within professional tasks), now time had accelerated to the extent that we constantly have multiple competing tasks in several agendas.

The acceleration of time required different tools, among which were online chats and social media which helped to synchronize time in the "timeless" situation. Even before coronavirus, scholars have argued that the life rhythms of modern people have been accelerating, and "it becomes rational to organize daily life in a flexible way whereby particularly new mobile technologies can be used for the coordination and synchronization of action chains" (Rosa, 2013: 235). Instead of feeling that the schedule has become flexible and controllable with the help of technologies compensating for the lack of face-to-face communications in self-isolation, our interlocutors reported just the opposite; they were overburdened by constant online events, messaging and working $24 / 7$, presenting papers at conferences at night (when these are working hours in another time zone), etc. Our participants write:

The coronavirus emergency and all social changes that it introduces actually increases the workload of people like us. The social activity online becomes extremely high. All real conferences were cancelled, but academics rush to organize even more online things. As a result, you cannot leave your work table; you do not even take breaks for travel to your workplace and back; you are just locked inside and chained to your laptop. "I am working 14 hours per day," a colleague tells me in a private conversation.

(Kristina, April 2020) 
The whole social life has moved online, which has increased my attachment to the phone, and it makes me feel like I'm being cornered.

(Valeria, March 2020)

Soon, immediate responses to incoming work tasks via online chats (Telegram, WhatsApp, Messenger, etc.) became the new professional demand, the idea of "working hours" became vague, and the privacy of communication (one can write only to those one personally knows well) faded away. Getting messages at any time of the day became a kind of norm, though associated with frustration and the need for additional negotiations. The new norms were generated in constant remote interactions:

I was able to return to the unfinished work questions only after my daughter fell asleep (23:10), and completed the slides $<\ldots$. .> Then, I sent them to the common chat and received a message from one of my colleagues "Is it possible, if not difficult, to send non-urgent messages at an early/late time using the Send without sound $\langle\ldots$. . $>$ function?". On the one hand, it's embarrassing that he was (possibly) woken up or disturbed, although the message was not addressed to him, while on the other hand, I caught myself thinking that I expect everyone to be responsible for ensuring own digital comfort somehow by default, because they can change settings for notifications on their devices. This reaction turned out to be interesting and unexpected, because I myself am used to receiving messages at night, and it seems that in a pandemic, the probability and intensity of night correspondence has only increased.

(Valeria, June 2020)

The acceleration of time becomes evident even for the ones reporting that there was nothing new for them in the corona lifestyle (they were used to working remotely, had no little kids, and had rare social contacts outside their households). Now, they have to synchronize themselves with the common growing tempo and elaborate special strategy of coping with overburdening:

Solitude is my remedy. But now I feel attacked online. Everybody wants to organize something, to discuss, to reflect together on the current crisis; people compete in making statements and producing content. I have to find a way to reduce the noise. Hiding in a countryside is a good solution: you have to interrupt this work flood for some other practical activities; otherwise you won't survive.

(Kristina, April 2020)

During the corona times, the coordination of different activities becomes intensive and essential, but also becomes a source of additional burden and exhaustion. Additional challenges emerge for our participants: how to define the boundaries of personal and collective working time as well as individual and collective goals and priorities, while working on projects without a certain time and space schedule.

When time changes its tempo, it loses its direct connections with the horizons of the past and present, and cannot be synchronized with the reference group; our reflections 
about the self intensify, as "our sense of who we are is virtually a function of our relationship to space, time, fellow human beings, and the objects of our environment (or to our action and experience)" (Rosa, 2013: 224). Metaphorically, we could say that we lost stable base for routine self production in an unstructured time with unstructured activities and multiple tasks, which arrive simultaneously from the private (home) and the public (work) domain. It becomes difficult to schedule our own tasks, and even harder to synchronize them with the academic community we correspond with. Therefore, we greet these changes with an emotional response.

Our narratives become full with reflections on different "objective" and "personal" temporalities, which do not match with each other; and this creates an existential sense of an interrupted life, a time for reconsidering our personality:

The greenery has blossomed. Feeling strange. As if this spring is not ours, as if it passes by, not for us, as if we have no right to notice it, because we are in quarantine ... As if my life, human one, is almost completely at home, and everything that happens on the street, in nature, began to occur in different time dimensions.

(Irina, May 2020)

Time not only became accelerated, but also became condensed with the tasks that usually have to be performed in other places (which guaranteed that they do not overlap).

\section{Merging Professional and Private Spaces}

The organization of time appears to be closely connected with space. The tasks that used to be associated with certain locations now become unanchored. They can accumulate into the same space and therefore, time. Writing, teaching, answering emails, carrying out interviews, cooking dinner, cleaning, washing, doing the laundry, Skyping, and caring for kids becomes a "here and now" issue, and one has to multi-task as never before:

While listening to the P. seminar, I brought some food, and on the way took the clothes out from the washing machine.

(Elena, April 2020)

We hardly work on the creation of spatial boundaries between our professional and private life, which are important for comfort and boundary of the academic self:

Today my partner moved his desk from the bathroom (yes, his desk was in a bathroom) to a small empty room ... It turned out to be almost a real office. I tried to work at this table a little bit in the evening - it is much more comfortable ... [In this room] it turns out to be like separating oneself from the "home", to feel this border between "home" and "work", the maintenance of which has become very important for me. 
However, not all of our efforts led to results (even when the majority could finally organize extra space for maneuverings), as private space became inhabited with new "virtual" persons, which caused an impractical inconvenience and emotional disturbances. We also started to experience our family members' presence at our "working places", as we ourselves were interfering in the private spaces of our colleagues and interlocutors:

Together with another lecturer I conduct a lesson (online), at the same time I sit with my daughter, who climbs into the computer $<\ldots>$ At the end of the lesson, the daughter still draws attention to herself - when I tell the students something like "when we want to go and study power relations ...," the daughter sits nearby and loudly (and responsibly) says that you can't go anywhere, because its quarantine.

(Marina, March 2020)

In the example above, Marina is located in different social spaces at the same time (the virtual private ones of her students and the other lecturer; and her own room with her daughter), simultaneously performing as a lecturer and as a mother. The home space ("first place") appears to be the place that has to serve all of the functions that have previously been performed in "second" (workplace) and "third" (cafes, main streets, playgrounds, etc.) places (Oldenburg, 2000). Now, all these places merge with each other.

Habitual and recreational practices, such as "eating out", walking with the children, or meeting with friends became reduced or unavailable, but happened with new coordinates:

On the balcony to our left, a woman (sometimes a man joins her, apparently her husband) continues to regularly walk her granddaughter. She still scrapes the concrete floor of the balcony with a small spatula designed for a sandbox, kicks a small ball, collects some plastic molds, also, apparently, intended for a sandbox. On other balconies, people read books, check their smartphones, hang up their laundry, just sit in the sun, walk from side to side, smoke, of course.

(Vadim, April 2020)

The confusing and conflicting overlays of activities, their accumulation in the same time and space requires new practices of time navigation, time balance, and special control. This navigation becomes an uneasy task as it requires constant re-negotiations with colleagues, students, family members, and friends. Additionally, all this communicational structure became loose: colleagues and students are in the same situation of being overburdened; among family members, some became more spatially close (if all are working from home) and the rest are much more distant (the elderly); friendship changes under the intensification of on-line transnational connections, and the reduction of face-to-face interactions.

In general, the participants report changes in their perception of time and space, which derived into the process of constant reflections about the self, boundaries, negotia- 
tions about everyday life practices, coping with emotions, and balancing different roles. ${ }^{6}$ We argue that the self experienced a massive reflection triggered by the problematized structures of time and space which were previously determined by life-work and privateprofessional boundaries and balances. The participants experienced this as requiring constant negotiations and a struggle with their own and others' cognitive and affective positions, practices and identities; they elaborate special strategies to navigate themselves into time and space; they try to schedule the fluid workload, share duties, reorganize space into sub-spaces; create a quasi-office at home, etc. They try to retain a tactical control over life while losing control over strategical planning.

\section{Self under Threat: An Emotional Response}

In this section, we turn to the emotional responses of our interlocutors to the changes in their everyday life and their coping with dilemmas significant for their self. Looking at the affective dimension in the narratives of the researchers, we ask how our academic self is expressed emotionally under outbreak. A wide spectrum of emotions was expressed by the participants such as panic, anxiety, nervousness, tension, hypochondria, helplessness, sadness, depressive state, boredom, fatigue, exhaustion, anxiety, spleen, paralysis of will, anger, irritation, annoyance, outrage, sympathy, empathy, pity, pride, joy, rise, happiness, and optimism.

Unknown and dangerous threats (up to catastrophes or apocalypses as participants defined these threats) interfere with our lives. Subjectivity became fragile in the "catastrophic" social changes under the conditions of "disaster": "Experience of loss of a moral world is a kind of social bereavement connected to both man-made and natural disasters and registered in the individual and collective body as a sadness, disorientation, anomie, and unfulfillable longing" (Wilkinson, Kleinman, 2016: 9).

This fragility is connected not only to virus and biological risks; ${ }^{7}$ a work-life balance and professional obligations are perceived as under the threat that we cannot be "good academicians" anymore (and even don't quite understand what it means now). We explore emotions which are expressed in connection to everyday fulfillment of working obligations while our system of reference (a kind of moral world) is lost.

Our participants notice that they learn new formats of work quickly (e.g., teaching and field research online) and they work more; however, they evaluate their productivity as low and academic performance as poor. There are also gendered peculiarities in productivity -females who have both teaching and childcare obligations were less productive during their COVID-19 related self-isolation, compared to males (Viglione, 2020). Additionally, "the pandemic changed the priorities of academic mothers in a direction that is unfavorable to their careers: mothers devoted most of their time to teaching duties and stopped research" (Minello et al., 2021).

6. We do not discuss here the vital fears of getting ill or infecting close ones, and the efforts made by the participants to stay safe and keep their children and elderly relatives safe as well.

7. The existential and vital fears and the anxiety of being infected, which are intensively articulated by the project participants and expressed in emotional language, are beyond the scope of this article. 
Both women and men in our project report their non-productivity (though women tell more about their conflicting work-care demands) causing anxiety, shame, and guilt. ${ }^{8}$ Anxiety (in relation to uncertainty in COVID-19, see also Rebughini, 2021), an exhaustion of cognitive overload, and tiredness appear as reactions to changing lifestyle patterns and societal situations. The descriptions of situations having catastrophic overtones in diaries as self is connected to vital risks and instability of various institutions such as healthcare, economics, and education. The personal working plans are tightly interwoven with other crisis conditions, vital risks are marked by professional belonging; special efforts are done in order to manage emotions and maintain a workable state, but this does not help much. Anxiety, panics, tiredness constantly accompany us:

I sleep very badly, I have disturbing dreams, I wake up on alarm clock (to have time to work before the daughter gets up). In my dreams everything usually happens amid coronavirus, for some reason my colleague anthropologist turns out there (I guess that is how my brain is trying to remind me about hygiene, washing hands). I wake up tired. Started to drink coffee at evenings to work. A vicious cycle . . . I think that there is no reason not to panic and greenlight the anxiety. Changes to constitution, fall of a ruble, closed borders, cancellations of working plans, the threat of economic crisis due to the pandemic, threat of virus, everyday challenges (working by the monitor, limitation of contacts, children).

(Marina, March 2020)

Anxiety becomes the central category in emotionally saturated narratives because it appears situationally and becomes a background for everyday routines. Constantly focusing on problems makes participants feel even more anxious and frustrated, as discourse (in networks and the media) is increasing anxiety. The virus is social and we are all forced to be involved in the virus discourse, but sometimes we want to limit its presence and free cognitive resources for something else:

In the last days I am trying not to read the news about the epidemic at all. I am tired of them, just as I am tired of discussions in social media about it. Obviously, most rapidly the virus is spreading and infects the informational space, infects discourse. We are all not just supposed to discuss the pandemic, but as if we cannot undiscuss it. We cannot break away from it, cannot shift the focus.

(Vadim, March 2020)

The inability to act in a "proper way" causes guilt and shame for being academically unproductive and unable to manage routine tasks, both in the professional and the personal spheres. These moral emotions demonstrate reactions to these violations of cultural codes (standards), when oneself "(not) do the right thing” (Haidt, 2003; Turner,

8. We should notice that here we explain the subjective experiences of studied academicians but their real productivity was not explored. We know from the literature that there was an increase in publications in 2020 (compared to the same period in 2019), with less output from women (Else, 2020). This does not confront the evaluations of our informants as they choose the coping strategy of overworking to get rid of anxiety, as we will see further. 
Stets, 2006; Creed et al., 2014). In this case, moral emotions express a distortion of basic references, and create dilemmas significant for the academic self. We are expected to be productive, disciplined, and control the circumstances (including time and space), but we do not manage to. Loss of self-control and the (subjectively experienced) decline in academic productivity challenged our subjectivity - we do not know who we are without our productivity and evaluation by others. We are confused and try to discipline ourselves, but we are not successful enough in these efforts.

Guilt and shame are usually associated with breaking promises and the inability to fulfill obligations: academics blame themselves for being unproductive, not able to concentrate, losing the academic race (they also feel guilty for breaking the rules of social distancing, or spending little engaged time with family):

Two days couldn't make myself work. I woke up, walked with the dog, hung out in Facebook, - hardly wrote down a couple of paragraphs for the article, Facebook again, the evening walk with the dog - more news - lights out.

(Victor, March 2020)

Participants endlessly repeat that their non-productivity causes guilt and shame:

Creative paralysis. The article is postponed, books are postponed.

(Leonid, April 2020)

I feel guilty because I cannot react [on incoming work tasks] quickly. I want to work and work all the time I can ... but anyways I have feeling of anxiety and guilt because of the tasks that are postponed.

(Marina, May 2020)

Its 2-2.30 pm ... I feel that I've done so little. As a result, during following hours I have written two short applications on [foreign language] ... Received reviews for the article ... Trying to find a native speaker for proofreading another article ... In the evening, attended Datacamp, studied one chapter on sql ... Trained [foreign language] a little bit. But the rest of the time I hang out in social media, watch stupid videos. I feel myself time killer and idler.

(Ivan, April 2020)

An "obsession" with productivity and control becomes the reaction to the vanishing system of referents; however, the shared feeling expresses that we "lost the race", though the work load has expanded to overtime, weekends, and night time:

Since the morning I am getting messages in working chats and working emails - I am slightly disappointed, because I have a feeling as if I was skipping the work, although its Sunday and I already have working plans. But I still cannot get rid of the feeling that it's a race I already lost, while still can't get off the distance.

(Valeria, May 2020) 
The participants discovered that the collective rhythms of their social and professional lives have been disturbed by self-isolation, distant teaching, and the absence of field research and face-to-face communication. We struggle with the new condition, but express our feelings and emotions of not being successful, not managing to organize ourselves well enough, feeling guilty, and endlessly reflecting on our self.

\section{The Academic Self at the Start of Pandemic: Reflexive and Fragile}

Here we are interested in what happened to self when we lost the criteria of our relevance (which to a large extent had been created in interactions with colleagues) and communications itself lost its previous structuring by time and space. We do not meet each other in university corridors or conferences anymore to learn recent news and gossip, or show enthusiasm for a new project, or get spontaneous feedback. We will demonstrate that the self of academicians has been reconsidered, and narrativization became a tool to do this.

\section{The Academic Self Withdraws from Face-to-Face Communications}

In the time of COVID-19, the breakdown of the content of work did not change radically, but had to be brought online and adapted to these new challenging and limiting conditions. As a whole, privileged academicians perceived themselves as fragile and vulnerable, as distant work caused many troubles from the beginning of self-isolation. The self of academicians is to a large extent produced via the juxtaposition within reference group(s) in everyday routine face-to-face performances in the working time and space. Scholars claim that absence of "real human interactions", the demise of narrative dimension of human lives during COVID-19 leads to emptying our human experience (Fernandez, 2021), and a feeling of isolation emerges as the result of distancing from one's colleagues on a daily basis (Utoft, 2020).

The pandemic changed not only the practices, but the embodied positioning of self within the social (professional) group, thus limiting opportunities for self-presentation. In order to maintain self, we have to work a lot, demonstrate results and receive approval, not only for our strategic achievements (top-rank publications), but also on our engagement, which is the personal embodied inclusion in the informal life of the scientific community. In the light of losing these informal practices, we understand how academic life is embodied in networking and human communications in a numerous occasions in certain space and time:

I wondered why we are canceling all conferences (today one more), because some can be held via Skype (especially small ones), and it's not so difficult. The essence and fabric of the conference is probably not in the scientific component (well, well, not only) - to come, move, treat it as an event, hang out, break out of one academic routine (and end up in another). This is how you learn new things about conferences through the pandemic, and about scientific life in general.

(Elena, March 2020) 
Online communication with colleagues still causes feelings of joy and unity (although it does not happen spontaneously), should be organized and have an agenda, but causes physical discomfort and requires more concentration:

We conducted Zoom with the St. Petersburg office. It was great to see everyone again. We discussed who _ survived_, different plans and just joy. I feel support, some kind of unity, solidarity. In general, there are many pleasant feelings.

(Svetlana, June 2020)

Systematic face-to-face verbal and non-verbal interactions used to be a part of our routinized evaluation and recognition. An academic reputation includes validation by the professional community; therefore, we are constantly sending each other signals that allow us to judge of our own or someone else's competences (Sokolov, 2020, 2021). Beside formal results, numerous informal signals allow scholars to express themselves in relevant displays, and to decode the current dispositions in professional fields. In other words, via informal communication in "second" and "third" places (Oldenburg, 2000), academic relevance and "proper" performance is verified.

The self is built via practices and interactions which are routinized, inscribed into a certain temporality, and are fixed into a certain space and time with a certain rule. This self was constantly produced in mutual personal exchanges of the norm and rule of a "suitable" working load, distributed in space and time, though still relatively flexible. Beside this networking appears to be the means of belonging and support in the formal structure of academy. Finding a team or a protective leader is no less important for academic sustainability than the approval of fitting meritocratic ideals of intellectual excellence (Gaiaschi, 2021).

This approval in everyday routine face-to-face performances was lost in corona time, and threatened the academic self. Various forms of academic networking and engagement were radically and rapidly changed. This rupture of tradition has led us to selfreflection in the attempt to recognize our place in seemingly changing social structure:

In the dining room I meet with [three colleagues]. We talk for about 30 minutes. Everyone is very complaining about the remote format. [Soon] my course starts. So I am listening, collecting information. I have no idea how to teach remotely. It seems to me that this is death for the teacher.

(Irina, March 2020)

Routine face-to-face juxtaposition, crucial for maintaining the academic self, became blurred and uncertain, and academic researchers lost their inspiration (Utoft, 2020). We suffer from the lack of a "humane presence" and try to compensate it with new rituals, examine new actions and shape new norms, tastes, and politics; in other words, frames of reference for our academic self: 
In the evening, a meeting of our institute laboratory was held in zoom. Interesting, albeit a little sleepy. It seems that the speaker and all the participants in the meeting more often than necessary say "thank you all for the fact that despite ..." and "sorry for the technical overlaps", although there is a feeling that this is just compensatory factual rhetoric, there is not enough live presence.

(Leonid, April 2020)

\section{The Narrativization of Experience: The Reflexive Self}

As we lost the system of relevance and feel that our academic self is under threat, we try to cope. Among the copying strategies are reflexivity and the extensive narrativization of ones' experiences (certainly, not all scholars tend to narrate their experiences, here we refer only to the group we studied). As we mentioned at the beginning of the article, participants felt a need for writing diaries, which is the narrativization of their subjective experiences:

I began to write something down just to remember the days.

(Svetlana, April 2020)

This diary is very useful to me ... Very disciplining.

(Nina, June 2020)

Under crisis (or even conditions perceived as a catastrophe), we reconstruct our academic routine, but not to become winners in the academic race (subjectively we already lost it, as participants note) in the old system of references, but to reconsider the new one, which is adaptive for the new conditions. This is why we need a constant narrativization of our reflections, and a synchronization via extensive online communication. Expressed emotions point at the frames of reference of our academic selves, that is, at its most vulnerable parts. We managed to reconsider the new frames of reference and our personal disposition within it relatively quickly.

The rise in online communication, "obsessive productivity", the many public reflections in social media, new skills, and new forms of interactions create new dispositions in the professional field. We learned the skills of online interviewing and ethnographical work; we coordinate activities via chats; we use to work with those whom we never met in person. Many institutional rules are changing since we observe less rigidity in bureaucratic demands, development of new requirements (technical skills, formats of teaching and research), absence of international academic traveling, and offline fieldwork. The "Zoomification", the reduction of academic mobility, and the increase of their work load became the new academic routine. Researchers were ambivalent and uncertain about the changes that would remain with us after everything is over. As one of participant summarized in May, 2020, 
When the quarantine is over ... people will have to live like in 2019. And many will be scared. Coronavirus is a state of mind. The new existential order. Virus will be gone, but its' phantom will remain.

(Leonid, May 2020)

In a few months, emotions and practices were routinized, the self did not need that extensive reflection, and restrictive measures also became less rigid and more uncertain. The motivation to narrate new experiences declined, and with every new "wave" of the research and diaries' collection, we found that the writing was running low, and by the mid-autumn of 2020, the enthusiasm was mostly over, although with some exceptions. Intensive emotions were expressed less and less, while narratives became shorter: "Virus kind of encapsulated. It is somewhere" (Elena, May 2020), and "Just ordinary life" (Yana, May 2020). Or, perhaps, it became difficult for participants to keep the same level of emotionalization as before:

The very thought of daily registering my emotions about the closed borders, zoomification of communication, death of industries, and most importantly - the standing behind all this amazing incompetence and lies and hypocrisy of the epidemic services, which authority turned out to be higher than presidential one, almost caused panic attack in me ... I cannot think about it anymore, write and talk.

(Leonid, September 2020)

Participants started to look for new references within unstable social coordinates in order to reconsider their professional everyday life patterns, to make them habitual, and it was the reflexive self that made them do this. In the autumn of 2020 (or sometimes earlier), when the majority had lost interest in writing diaries, new practices were integrated into their self-perception, making us less reflexive about emotions and crucial changes brought on by the pandemic. Self-evaluations and evaluations relocated to endless Zoom meetings, social networks, including transnational ones, and to a very closed circle - the self becomes stabilized into the new system of references and, we guess, became more individualistic and flexible. When the new social order becomes inhabited, the need for narrativization has gone:

I caught myself on thinking that every day I think before going out, that I am about to write something down in a diary. But when I get home, I understand that I haven't recorded anything. I didn't think about anything. It became impossible to fix anything, everything became commonplace and everyday life routine. Nothing becomes an eyesore, does not stand out, does not bother.

(Ella, May 2020)

\section{Conclusion}

During the first months of COVID-19, in relating self-isolation, we observe a rise in the narrativization of people's experiences, including the groups that are not at the highest 
risk of getting infected. With the example of academic workers, we explore why there was such an intense emotional response towards the ruptures in their everyday/professional practices. We argue that the professional self is reflexive, and actively reacts to changes in temporal and spatial structures. They derived into overload with duties (all happening "here and now"), the social clues of self-evaluation in the academic world about new virtual performance and professional position were lacking, and the feelings of being dissatisfied, anxiety, shame, and guilty emerged.

In this article, we demonstrate how the "academic self" in a privileged social group was unexpectedly challenged by the pandemic, as researchers express their insecurities, vulnerabilities and frustrations. We show that such an intensive emotional response as related to the professional self was caused by the acceleration of time and the collapse of boundaries between the private and public spaces. Time was perceived as a limited resource; researchers became overburdened with professional duties and online communications; activities, previously performed at a different time and space, competed with each other.

Unstructured time and space, and overlapping tasks and duties resulted in subjective experiences of low productivity, that is, the inability to act in a "proper" academic way. This was causing anxiety, shame, and guilt. We feel that we are losing the academic race and also not managing well in other spheres of life. The academic self is, to a large extent, constructed in everyday academic interactions, which gives us the tools for self-evaluation and self-construction, while results of work and activities are approved (or not) by colleagues formally and informally. Unfortunately, this was lost in on-line work as well. Then, we turn to reflexivity - an act of self-reference - that help us to reconsider the frames of reference of our professional self, its norms, values, rules, symbols and signs of success, and our place in it.

Academicians - despite their quite safe positions - felt vulnerable. Their sense of belonging to academia was threatened by the unavailability of the habitual ways of practicing work and group communications. We demonstrated an intensification of labor along with the rise of narrative reflexivity and strong emotional responses as the reactions to the pandemic changes. These lasted for some time (several months) until new patterns of work were habitualized (we got used to online teaching, interviewing, developing projects, etc.) and elements of offline communication came back into the lives of scholars. However, the long-term effects of the pandemic on various specific groups of academic workers (e.g. women or young scholars) will need to be studied further.

\section{References}

Adams M. (2003) The Reflexive Self and Culture: A Critique. British Journal of Sociology, vol. 54, no 2, pp. 221-238.

Bidwel L. M., Grether S. T., Pederson J. E. (2020) Disruption and Difficulty: Student and Faculty Perceptions of the Transition to Online Instruction in the COVID-19 Pande- 
mic. COVID-19, Vol. 2: Social Consequences and Cultural Adaptations (ed. J. M. Ryan), London: Routledge, pp. 31-46.

Castells M. (1996) The Information Age: Economy, Society and Culture, Vol. 1: The Rise of the Network Society, Oxford: Blackwell.

Creed W. E., Hudson B. A., Okhuysen G. A., Smith-Crowe K. (2014) Swimming in a Sea of Shame: Incorporating Emotion into Explanations of Institutional Reproduction and Change. Academy of Management Review, vol. 39, no 3, pp. 275-301.

Crook P. S. (2020) Parenting during the COVID-19 Pandemic of 2020: Academia, Labour and Care Work. Women's History Review, vol. 29, no 7, pp. 1226-1238.

Damsholt T. (2020) Times of Corona: Investigating the Temporalities of Everyday Life during Lockdown. Ethnologia Europaea, vol. 50, no 2, pp. 137-155.

Else H. (2020) COVID in Papers: A Torrent of Science. Nature, vol. 588, p. 553.

Fernández A. M. (2021) Beyond Health and Wealth: The Impact of COVID-19 and AntiCOVID-19 Measures on the Narrative Dimension of Human Life. Academia Letters, art. 660 .

Fodor E., Gregor A., Koltai J., Kováts E. (2020) The Impact of COVID-19 on the Gender Division of Childcare Work in Hungary. European Societies, vol. 23, sup. 1, pp. 95-110.

Frank A. W. (1995) The Wounded Storyteller: Body, Illness, and Ethics, Chicago: University of Chicago Press.

Gaiaschi C. (2021, September 3) One Step Back or One Step Forward? The Ambivalent Gender Effects of the Neoliberal Academia [Conference Presentation]. 15th ESA Conference [RN14_T10: The Academia and civil Service as labor markets]

Giddens A. (1990) The Consequences of Modernity, Cambridge: Polity Press.

Giddens A. (1991) Modernity and Self Identity: Self and Society in the Late Modern Age, Stanford: Stanford University Press.

Goffman E. (1990) The Presentation of Self in Everyday Life, London: Penguin.

Haidt J. (2003) The Moral Emotions. Handbook of Affective Sciences (eds. R. J. Davidson, K. R. Scherer, H. H. Goldsmith), Oxford: Oxford University Press, pp. 852-870.

Hjálmsdóttir A., Bjarnadóttir V. S. (2020) "I have turned into a foreman here at home": Families and Work-Life Balance in Times of COVID-19 in a Gender Equality Paradise. Gender, Work and Organization, vol. 28, no 1, pp. 268-283.

Holavin A. O. (2020) Social'noe bezdejstvie na rannih jetapah pandemii COVID-19 [Social Inaction at Early Stages of the COVID-19 Pandemics]. Sociological Studies, no 11, pp. 139-148.

Illouz E. (2007) Cold Intimacies: The Making of Emotional Capitalism, Oxford: Wiley.

Kınıkoğlu C. N., Can A. (2021) Negotiating the Different Degrees of Precarity in the UK Academia during the COVID-19 Pandemic. European Societies, vol. 23, sup. 1, pp. 817830.

Lerner J. (2015) The Changing Meanings of Russian Love: Emotional Socialism and Therapeutic Culture on the Post-Soviet Screen. Sexuality \& Culture, vol. 19, no 2, pp. 349368. 
Minello A., Martucci S., Manzo L. K. C. (2021) The Pandemic and the Academic Mothers: Present Hardships and Future Perspectives. European Societies, vol. 23, sup. 1, pp. 82-94.

Oldenburg R. (2000) Celebrating the Third Place: Inspiring Stories about the "Great Good Places" at the Heart of Our Communities, New York: Marlowe \& Company.

Oslon A. (ed.) (2021) Sociologija pandemii: proekt koronaFOM [Sociology of Pandemics: CoronaFOM Project], Moscow: Institute of the Public Opinion Foundation.

President of Russia (2020) Obrashhenie k grazhdanam Rossii [Appeal to Citizens of Russia]. Available at: http://kremlin.ru/events/president/news/63061 (accessed 20 December 2021).

Rebughini P. (2021) A Sociology of Anxiety: Western Modern Legacy and the COVID-19. International Sociology, vol. 36, no 4, pp. 554-568.

Reuschke D. (2021) Homeworking during Lockdown: Growth, Productivity and its Longterm Future in the UK. [Conference Presentation]. 15th ESA Conference [SP12: Discussing the Effects of the Lockdown: The Expansion of Remote Work and Inequalities in Home Learning].

Risi E., Pronzato R., Fraia G. D. (2020) Everything is Inside the Home: The Boundaries of Home Confinement during the Italian Lockdown. European Societies, vol. 23, sup. 1, pp. 464-477.

Rosa H. (2013) Social Acceleration: A New Theory of Modernity, New York: Columbia University Press.

Sokolov M. (2020) Sociologija podozritel'nosti: teorija rekomendatel'nyh otnoshenij s primerami iz akademicheskoj zhizni [Towards a Sociology of Suspicion: A Theory of Recommendational Relations with Applications to the Academic World]. Russian Sociological Review, vol. 19, no 1, pp. 106-138.

Sokolov M. (2021) Akademicheskie reputacii v rossijskoj sociologii: opyt izmerenija [Academic Recognition in Russian Sociology: A Study Using Reputation Surveys]. Sociological Studies, no 3, pp. 44-56.

Tahir S. (2021) Remote Working during the Pandemic and Technostress. Academia Letters, art. 1017.

Tartakovskaya I. (2021) Doverie pered licom pandemii: v poiskah tochki opory [Trust in the Face of a Pandemic: In Search of Common Ground]. Sociological Journal, vol. 27, no 2, pp. 68-89.

Turner J. H., Stets J. E. (2006) Moral Emotions. Handbook of the Sociology of Emotions (eds. J. E. Stets, J. H. Turner), Boston: Springer, pp. 544-566.

Utoft E. H. (2020) "All the Single Ladies" as the Ideal Academic during Times of COVID-19? Gender, Work and Organization, vol. 27, no 5, pp. 778-787.

Viglione G. (2020) Are Women Publishing Less during the Pandemic? Here's What the Data Say. Nature, vol. 581, no 7809, pp. 365-366.

Wilkinson I., Kleinman A. (2016) A Passion for Society: How We Think about Human Suffering, Berkeley: University of California Press. 


\section{Академические работники на карантине: рефлексивность и уязвимость привилегированной группы в начале пандемии}

\section{Дарья Литвина}

Научный сотрудник факультета социологии (программа «Гендерные исследования»), научный сотрудник Института междисциплинарных медицинских исследований (ИММИ), Европейский университет в СанктПетербурге

Адрес: ул. Гагаринская, д. 6/1А, г. Санкт-Петербург, Российская Федерация 191187 E-mail: dlitvina@eu.spb.ru

\section{Анна Темкина}

$\mathrm{PhD}$, профессор факультета социологии, содиректор программы «Гендерные исследования», Европейский университет в Санкт-Петербурге

Адрес: ул. Гагаринская, д. 6/1А, г. Санкт-Петербург, Российская Федерация 191187

E-mail: temkina@eu.spb.ru

Цель данной статьи - проанализировать изменения, которые произошли в жизни социальных исследователей в первые месяцы пандемии 2020 года, когда и работа, и повседневность, и академическая рутина стали проблематизироваться и преображаться. Статья опирается на данные дневников, в которых исследователи с академическим опытом в социальных и гуманитарных науках фиксировали свою повседневную жизнь и рефлексировали по поводу ее изменений. Нас интересует, почему «академики» относительно привилегированная группа, которая имела возможность безопасной удаленной работы и выполнения своих профессиональных обязательств во время периода самоизоляции, - испытывали фрустрацию и сильные моральные эмоции, связанные с работой. Мы показываем, что основные координаты — пространство и время, утратили привычную структуру, препятствуя продуктивности и угрожая «правильному», дисциплинированному и продуктивному академическому «селфу». В дневниковых нарративах участники проекта описывают эмоциональные реакции на эту ситуацию, в том числе негативные чувства тревоги и вины за снижение продуктивности. «Новая» академическая реальность характеризовалась соединением (прежде разделенных) задач в одних и тех же временных и пространственных координатах и, как следствие, ощущением постоянной перегруженности. Одновременно с этим, академические сотрудники лишились рутинных форм профессиональной коммуникации и нетворкинга на повседневной основе. Данные показывают, что академические сотрудники ориентированы на самодисциплинирование и продуктивность, и их профессиональный «селф» производится через нормативное оценивание, самооценивание и сопоставление с референтными группами. Когда правила изменчивы, нестабильны или постоянно нарушаются, то это становится угрозой для «селф». Моральные эмоции служат маркером данного процесса до тех пор, пока «новый» социальный порядок не становится обжитым и рутинизированным. Ключевые слова: COVID-19, пандемия, эмоции, академия, селф, идентичность, дневники 